Research Article

\title{
Functionalized Glutathione on Chitosan-Genipin Cross-Linked Beads Used for the Removal of Trace Metals from Water
}

\author{
Samira R. Akaji and David Dewez $(\mathbb{D}$ \\ Laboratory of Environmental \& Analytical Biochemistry of Contaminants, Department of Chemistry, \\ University of Quebec in Montreal, Montréal, C.P. 8888 Succursale Centre-Ville, Canada
}

Correspondence should be addressed to David Dewez; dewez.david@uqam.ca

Received 25 May 2020; Revised 3 August 2020; Accepted 27 August 2020; Published 14 September 2020

Academic Editor: Carlo Galli

Copyright (C) 2020 Samira R. Akaji and David Dewez. This is an open access article distributed under the Creative Commons Attribution License, which permits unrestricted use, distribution, and reproduction in any medium, provided the original work is properly cited.

\begin{abstract}
Functionalized glutathione on chitosan-genipin cross-linked beads (CS-GG) was synthesized and tested as an adsorbent for the removal of $\mathrm{Fe}(\mathrm{II})$ and $\mathrm{Cu}(\mathrm{II})$ from aqueous solution. The beads were characterized by several techniques, including Fouriertransform infrared spectroscopy (FTIR), thermogravimetric analysis (TGA), CNS elementary analysis, scanning electron microscopy (SEM), and atomic force microscopy (AFM). The effect of several parameters such as the $\mathrm{pH}$, the temperature, and the contact time was tested to optimize the condition for the adsorption reaction. The beads were incubated in aqueous solutions contaminated with different concentrations of $\mathrm{Fe}(\mathrm{II})$ and $\mathrm{Cu}$ (II) (under the range concentration from 10 to $400 \mathrm{mg} \cdot \mathrm{L}^{-1}$ ), and the adsorption capacity was evaluated by inductively coupled plasma optical emission spectrometry (ICP-OES). The adsorption equilibrium was reached after $120 \mathrm{~min}$ of incubation under optimal pH 5 for Fe(II) and after 180 min under optimal pH 6 for $\mathrm{Cu}(\mathrm{II})$. According to the Langmuir isotherm, the maximum adsorption capacities $\left(q_{\max }\right)$ for $\mathrm{Fe}(\mathrm{II})$ and $\mathrm{Cu}(\mathrm{II})$ were $208 \mathrm{mg} \mathrm{g}^{-1}$ and $217 \mathrm{mg} \cdot \mathrm{g}^{-1}$, respectively. Our results showed that the adsorption efficiency of both metals on CS-GG beads was correlated with the degree of temperature. In addition, the adsorption reaction was spontaneous and endothermic, indicated by the positive values of $\Delta G^{0}$ and $\Delta H^{0}$. Therefore, the present study demonstrated that the new synthesized CS-GG beads had a strong adsorption capacity for $\mathrm{Fe}(\mathrm{II})$ and $\mathrm{Cu}(\mathrm{II})$ and were efficient to remove these trace metals from aqueous solution.
\end{abstract}

\section{Introduction}

The development of urbanization including industrial and agricultural activities has been the main source of metal pollution in the environment. The continuous release of trace metal elements in water reservoir may represent a risk of toxicity for natural ecosystems and human health, since these metals are nonbiodegradable and can be bioaccumulated in aquatic organisms [1-3]. Therefore, water pollution by metals is still a global problem for environmental quality and public health. In particular, Fe(II) and $\mathrm{Cu}(\mathrm{II})$ are both nutrients at very low concentrations involved in many biological functions such as cofactors for enzymatic activities but become toxic at high concentrations [4-6]. According to the WHO standards, the acceptable limits of $\mathrm{Fe}(\mathrm{II})$ and $\mathrm{Cu}(\mathrm{II})$ in drinking water are $0.3 \mathrm{mg} \cdot \mathrm{L}^{-1}$ and $2.0 \mathrm{mg} \cdot \mathrm{L}^{-1}$, respectively [7]. Indeed, water with high $\mathrm{Fe}$ (II) content can represent a substrate for the development of bacterial contamination in the ducts [8]. It was reported that chronic exposure to $\mathrm{Fe}(\mathrm{II})$ may lead to adverse health effects, such as impaired hematopoiesis [9]. In addition, $\mathrm{Cu}(\mathrm{II})$ overload can induce adverse health effects, such as keratinization, gastrointestinal, liver, or kidney disorders [10-12].

To preserve water quality, different remediation strategies have been developed to control the concentration of trace metal elements in a freshwater reservoir. Until now, remediation methodologies have included chemical precipitation, reverse osmosis, coagulation and flocculation, oxidation, electrochemical treatment, ion exchange, solidphase extraction, adsorption on activated carbon, and biosorbents $[1,2,13]$. In particular, the use of adsorbents 
showed to be the most economical and effective method for the removal of metals from aqueous solution, without producing toxic sludge (by-products of treatment). Several types of adsorbent were studied such as clay mineral, activated carbon, porous carbon, porous carbon loaded with $\mathrm{ZnO}$ nanoparticles, nanomaterials, chitosan and modified chitosan, carbon nanotubes coated with alumina, zeolites, natural polymers, and mesoporous treated fish waste [14-29]. Among natural polymer adsorbents, the chitosan (CS) represented a "green" and eco-friendly compound for the adsorption of metals in solution, because of its hydrophilicity, biocompatibility, biodegradability, and biofunctionality properties [30]. The synthesis of CS is usually obtained by the alkaline deacetylation of chitin, a natural polysaccharide found in the exoskeletons of crustaceans like shrimps, crabs, prawns, and lobsters [31, 32]. To increase the stability and the capacity of CS beads, cross-linking agents are used such as glutaraldehyde, epichlorohydrin, and ethylene glycol diglycidyl ether, leading to the formation of a three-dimensional network [33-36]. However, these chemicals are known to be toxic to living organisms. In fact, the cytotoxic, mutagenic, and carcinogenic properties of glutaraldehyde were previously demonstrated [37, 38].

It is well known that the adsorbent property of CS is due to the presence of amine $\left(-\mathrm{NH}_{2}\right)$ (acetamide or primary amino) and hydroxyl (-OH) groups, providing coordination sites for the complexation of metals. To improve the maximal adsorption capacity of CS, the design of chelating CSbased resin has been the subject of many studies [21, 30, 39]. Previously, different sulfur compounds were added to CS, such as dithiocarbamate [40], thiourea or dithiooxamide [41], and mercapto acetic acid [42]. Recently, the ligand cysteine was used for the functionalization of CS to bind more efficiently metals in aqueous solutions [43]. However, other thiol compounds were not investigated and should be tested to determine the efficiency of new complexes. In particular, phytochelatins (PCs) are well-known thiol polypeptides, consisting of a chain of 2 to 11 units of glutathione ( $\gamma$-L-glutamyl-L-cysteinylglycine, GSH). In plant cells, these compounds are chelators involved in the transport of metals into the vacuole, maintaining the homeostasis of intracellular concentration of metals [44]. Since the synthesis of PCs is costly, its repetitive subunit GSH can represent a more practical alternative. In addition, the GSH is composed of three amino acids as $\gamma$-L-glutamyl-L-cysteinylglycine, providing the functional groups $-\mathrm{COOH}$, $-\mathrm{SH}$, and $-\mathrm{NH}_{2}$ for the complexation of metals [45].

The main objective of this study was to design a new complex CS-genipin by covalent cross-linking reaction and functionalized with GSH to obtain a strong adsorption property for metals in solution. It is known that genipin is a natural cross-linking agent derived from geniposide, a compound extracted from the fruit Gardenia jasminoides Ellis (Rubiaceae). This plant was traditionally used by Asian populations as a medicinal herb and food coloring, and its toxicity was demonstrated to be a thousand times (5000-10000) lower than glutaraldehyde. It was reported that genipin can make covalent bonds with amino groups of proteins and biopolymers such as CS [46-48]. For these reasons, we used in this study the genipin as a cross-linking agent to make the beads. The new beads were characterized by Fourier-transform infrared spectroscopy (FTIR), thermogravimetric analysis (TGA), CNS elementary analysis, scanning electron microscopy (SEM), and atomic force microscopy (AFM). In addition, we investigated their adsorption capacity in aqueous solution for both $\mathrm{Fe}(\mathrm{II})$ and $\mathrm{Cu}$ (II) ions, and the quantification was performed by inductively coupled plasma optical emission spectrometry (ICP-OES). The effect of different parameters (variables) was also investigated on the adsorption rate, such as the $\mathrm{pH}$, the temperature, the reaction time, and the adsorption isotherms. Therefore, this study determined the optimal condition for the adsorption of $\mathrm{Fe}$ (II) and $\mathrm{Cu}$ (II) ions on these new CS-genipin cross-linked beads with functionalized GSH (CS-GG).

\section{Material and Methods}

2.1. Material and Reagents. The CS (Kitomer ${ }^{\mathrm{TM}}$, MW $1600 \mathrm{kDa}, 85-89 \%$ D Ac) was obtained from Marinard Biotech (QC, Canada). The genipin was purchased from Challenge Bioproducts Co., Ltd. (Taiwan). The reduced form of glutathione at high purity was provided by Bio Basic Inc. (ON, Canada). The chemicals $\mathrm{CuCl}_{2}, \mathrm{FeCl}_{2} .4 \mathrm{H}_{2} \mathrm{O}$, and anhydrous ethanol were purchased from Sigma-Aldrich Chemical Co. All chemicals were of analytical grade and used as received without any additional purification. All subsequent experiences were carried out with Nanopure water provided by a Barnstead Nanopure water purification system (ThermoFisher Scientific).

\subsection{Preparation of Chitosan-Based Beads}

2.2.1. Preparation of Bead-Forming Solution. A mixture of CS ( $5 \mathrm{~g})$ and aqueous acetic acid $(250 \mathrm{ml}, 0.1 \%(\mathrm{v} / \mathrm{v}))$ was stirred at $150 \mathrm{rpm}$ for $24 \mathrm{~h}$ at room temperature to ensure total solubility of the CS. Then, a simple ultrasound device (Fisher Scientific Model 505 Sonic Dismembrator) was used to remove air bubbles in the solution before forming the beads.

\subsubsection{Gelification of Chitosan Beads under Alkaline} Condition. The previous gelatinous mixture was released through a syringe needle ( $1 \mathrm{~mm}$ in diameter) into $1 \mathrm{M} \mathrm{NaOH}$ solution with $70 \%$ alcohol, in which the CS was precipitated immediately to form gelatinous spherical beads. The obtained CS beads were thoroughly washed with Nanopure water followed by ethanol (70\%) until neutrality. The beads were kept in $0.01 \mathrm{M}$ of sodium phosphate buffer $(\mathrm{pH} \mathrm{7.0)}$ at $4^{\circ} \mathrm{C}$ until further use. Before using them, the beads were generously washed three times with ethanol (70\%) and three times with Nanopure water.

\subsubsection{Formation of Chitosan-Genipin Cross-Linked Beads.}

The CS beads obtained in the previous step did not have satisfactory mechanical properties. To improve them, the beads were cross-linked with genipin to reinforce the 
structure of the covalent bonds between CS and genipin. An amount of $50 \mathrm{~g}$ of CS beads was put into a cross-linking solution containing $5.6 \mathrm{mg}$ of genipin ( $0.05 \%$ of CS weight). The suspension was moderately stirred at room temperature during $48 \mathrm{~h}$. Then, the cross-linked beads were rinsed with ethanol (70\%) and Nanopure water to remove the excess of cross-linking solution.

\subsubsection{Glutathione Functionalization on Chitosan-Genipin} Cross-Linked Beads. An amount of $50 \mathrm{~g}$ of CS-genipin crosslinked beads was added to $200 \mathrm{~mL}$ of a solution containing $2 \mathrm{mg} \cdot \mathrm{mL}^{-1}$ of GSH and $0.1 \mathrm{mM}$ of genipin, which were then incubated at $25^{\circ} \mathrm{C}$ during $24 \mathrm{~h}$ under a mildly stirring. Before decantation, beads were rinsed with Nanopure water to remove the excess of by-products and other impurities. With this method, we obtained beads functionalized at their surface with a thin layer of GSH (CS-GG).

\subsection{Characterization of the Beads}

2.3.1. Fourier-Transform Infrared Spectroscopy Analysis. Fourier-transform infrared (FTIR) spectra were recorded using a Spectrum One spectrophotometer (Thermo Scientific Nicolet 4700 iTR) equipped with a universal attenuated total reflectance (UATR) device. The analysis was performed in the spectral region $\left(4000-500 \mathrm{~cm}^{-1}\right)$ with 32 scans recorded at a $16 \mathrm{~cm}^{-1}$ resolution.

2.3.2. Thermogravimetric Analysis. Thermogravimetric analysis (TGA) was done on native CS and CS-GG beads by using a TGA/MS analyser (TGAQ5000 Discovery MS). Experiments were performed under a dynamic argon atmosphere flowing at a rate of $15 \mathrm{~mL} \cdot \mathrm{min}^{-1}$ and at a heating rate of $2.5^{\circ} \mathrm{C} \cdot \mathrm{min}^{-1}$.

2.3.3. Microscopy Measurements. Scanning electron microscopy (SEM) was performed on CS and CS-GG beads to characterize their topography by using a field emission scanning electron microscope JEOL (model: JSM-7600F). In addition, atomic force microscopy (AFM) was used to analyze the surface topography of CS-GG beads with a Bruker MultiMode 8 AFM system.

2.3.4. CNS Elementary Analysis. The elementary analysis was carried out by using a Carlo Erba Instruments NA2500 series elemental analyser. The samples were dried, and $20 \mathrm{mg}$ was put in tin capsules to measure the percentage of $\mathrm{C}, \mathrm{N}$, and $\mathrm{S}$ elements.

2.3.5. Adsorption Experiments. All metal adsorption studies were performed in batch experiments by using $125 \mathrm{~mL}$ Erlenmeyer flasks containing $50 \mathrm{~mL}$ of trace metal solution and $1 \mathrm{~g}$ of CS-GG beads. Stock solutions were prepared at $500 \mathrm{mg} \cdot \mathrm{L}^{-1}$ of $\mathrm{Fe}(\mathrm{II})$ and $\mathrm{Cu}(\mathrm{II})$. The experiments were performed under the range concentration from 10 to $400 \mathrm{mg} \cdot \mathrm{L}^{-1}$ and different $\mathrm{pH}$ conditions (from 1 to 7 ), which was adjusted by using $\mathrm{HCl} / \mathrm{NaOH}$ solutions. The kinetics were studied at the optimum $\mathrm{pH}$ of 5.0 and 6.0 for $\mathrm{Fe}$ (II) and $\mathrm{Cu}(\mathrm{II})$, respectively, and under the constant temperature of $20^{\circ} \mathrm{C}$. The analysis was carried out in triplicate at regular time intervals (10 to $400 \mathrm{~min}$ ). Three Erlenmeyer flasks were prepared (as mentioned before) for each time interval, from which aliquots $(2 \mathrm{~mL})$ were taken to determine the quantity of metal ions adsorbed on CS-GG beads.

Equilibrium isotherm studies were carried out with different concentrations of metal ions (10 to $400 \mathrm{ppm}$ ) at different temperatures. The thermodynamic parameters were determined by changing the temperature to $20^{\circ} \mathrm{C}, 30^{\circ} \mathrm{C}$, and $40^{\circ} \mathrm{C}$ in a temperature-controlled shaking incubator (Infors HT Multitron Pro thermostatic). The flasks were agitated on a shaker at $150 \mathrm{rpm}$ during $2 \mathrm{~h}$. After the incubation, the solution was filtered and the concentration of metal ions was determined using inductively coupled plasma optical emission spectrometry (ICP-OES, Agilent model 5100, Agilent Technologies, USA). All experiments were performed in triplicate, and the average values were estimated. The quantity of metal ions was estimated per unit mass of the adsorbent according to the following equation:

$$
q_{e}=\frac{\left(C_{0}-C_{e}\right)}{m} v,
$$

where $q_{e}$ is the adsorbed amount of metal ions per unit mass of the adsorbent $\left(\mathrm{mg} \cdot \mathrm{g}^{-1}\right)$ at equilibrium, $m(\mathrm{~g})$ is the weight of the CS-GG beads, $C_{0}$ is the concentration of $\mathrm{Fe}(\mathrm{II})$ and $\mathrm{Cu}$ (II) before the adsorption, $C_{e}\left(\mathrm{mg} \cdot \mathrm{L}^{-1}\right)$ is the concentration of $\mathrm{Fe}(\mathrm{II})$ and $\mathrm{Cu}$ (II) after equilibrium with CS-GG beads, and $v(\mathrm{~L})$ is the volume of the solution.

2.3.6. Adsorption Isotherms. Equilibrium adsorption isotherms were used to determine the adsorption mechanism and capacity for metals. Some well-known ones are Langmuir, Freundlich, Temkin, Redlich-Paterson, Dubinin-Radushkevich, and Sips equations [49-51]. The adsorption isotherms of Langmuir and Freundlich models were used to describe the adsorption equilibrium of $\mathrm{Fe}$ (II) and $\mathrm{Cu}$ (II) ions on CS-GG beads. The experiments were performed at different temperatures $\left(20,30\right.$, and $\left.40^{\circ} \mathrm{C}\right)$.

The Langmuir isotherm assumed that the mechanism of metal ions' adsorption process took place as a monolayer on the surface of the adsorbent (beads). The linear form of Langmuir isotherm was expressed by the following equation:

$$
\frac{C_{e}}{q_{e}}=\frac{1}{q_{\max }} C_{e}+\frac{1}{K_{L} \cdot q_{\max }},
$$

where $C_{e}$ is the equilibrium concentration of remaining metal ions in the solution $\left(\mathrm{mg} \cdot \mathrm{L}^{-1}\right), q_{e}$ is the amount of metal ions adsorbed per mass unit of adsorbent at the equilibrium $\left(\mathrm{mg} \cdot \mathrm{g}^{-1}\right), q_{\max }$ (constant) is the amount of metal ions for a complete monolayer (mg.g ${ }^{-1}$ ), and $K_{L}$ is the Langmuir constant related to the affinity of binding sites $\left(\mathrm{L} \cdot \mathrm{mg}^{-1}\right)$, representing a measure of the adsorption energy. $q_{\max }$ and $K_{L}$ were evaluated from the intercept and the slope of the linear plot of the experimental data of $C_{e} / q_{e}$ versus $C_{e}$, respectively. To determine the adsorption affinity of $\mathrm{Fe}(\mathrm{II})$ and 
$\mathrm{Cu}(\mathrm{II})$ ions on CS-GG beads, the separation factor $R_{L}$ was determined. This factor was calculated by the following equation:

$$
R_{L}=\frac{1}{\left(1+K_{L} \cdot C_{0}\right)},
$$

where $R_{L}$ is a dimensionless separation factor, indicating the shape of the isotherm, $C_{0}$ is the initial concentration of metal ions, and $K_{L}$ is the Langmuir constant. The tendency of the adsorption process was indicated by $R_{L}$ values. When $R_{L}>1$, the isotherm was unfavorable; for $R_{L}=1$, the isotherm was linear; when $R_{L}<1$, the isotherm was favorable; for $R_{L}=0$, the reaction was irreversible.

The Freundlich isotherm assumed that the mechanism of metal ions' adsorption process did happen as a multilayer on a heterogeneous surface of the adsorbent (beads), given by the linear form of the following equation:

$$
\ln q_{e}=\frac{1}{n}\left(\ln C_{e}\right)+\ln K_{F},
$$

where $K_{F}$ and $n$ (or $1 / n$ ) are both a constant, indicating the adsorption capacity $\left(\mathrm{mg} \cdot \mathrm{g}^{-1}\right.$ ) and the intensity (degree of surface heterogeneity), respectively. The fitting plots based on Langmuir and Freundlich models for the adsorption of $\mathrm{Fe}(\mathrm{II})$ and $\mathrm{Cu}(\mathrm{II})$ are presented in Figures S2(a) and S2(b) and Figures S3(a) and S3(b).

2.3.7. Adsorption Kinetics. The adsorption on a solid surface can be controlled by several steps such as the boundary layer (film) or external diffusion, the pore diffusion, the surface diffusion, and the adsorption on a pore surface. We investigated the adsorption process of $\mathrm{Fe}(\mathrm{II})$ and $\mathrm{Cu}$ (II) ions on CS-GG beads by correlating our results with different kinetic models: the pseudo-first-order [52], the pseudosecond-order [53], and the intraparticle diffusion [54]. follows:

The linear form of the pseudo-first-order equation was as

$$
\log \left(q_{e}-q_{t}\right)=\log q_{e}-\frac{k_{1}}{2.303} t
$$

where $k_{1}$ is the pseudo-first-order rate constant $\left(\mathrm{min}^{-1}\right)$ of adsorption and $q_{e}$ and $q_{t}\left(\mathrm{mg} \cdot \mathrm{g}^{-1}\right)$ represent the amount of metal ions adsorbed at the equilibrium and at the time $t$ (min), respectively. The straight-line plots of $\log \left(q_{e}-q_{t}\right)$ versus $t$ were used to determine $k_{1}$ and the correlation coefficient $R^{2}$, which is shown in Figures S4(a) and S4(b).

Furthermore, the linear form of the pseudo-secondorder equation was as follows:

$$
\frac{t}{q_{t}}=\frac{1}{k_{2} \cdot q_{e}^{2}}+\frac{1}{q_{e}} t,
$$

where $k_{2}$ is the pseudo-second-order rate constant of adsorption $\left(\mathrm{g} \mathrm{mg}^{-1} \cdot \mathrm{min}^{-1}\right)$. The value of $1 / q_{t}$ was calculated from the experimental results and plotted versus $1 / t\left(\mathrm{~min}^{-1}\right)$ to obtain the biosorption rate constant $\left(k_{2}\right)$, shown in Figures S5(a) and S5(b).

Kinetics data were also fitted with the intraparticle diffusion model, which considers that if the rate-limiting step was the intraparticle diffusion, then the amount adsorbed $q_{t}\left(\mathrm{mg}^{-1} \mathrm{~g}^{-1}\right)$ at any time $t(\mathrm{~min})$ should be directly proportional to the square root of the contact time $t$. This model was defined by Weber and Morris [54], and the equation was given as follows:

$$
q_{t}=k_{i d} \cdot t^{0.5}+C
$$

where $q_{t}\left(\mathrm{mg} \cdot \mathrm{g}^{-1}\right)$ is the amount adsorbed at the equilibrium time $t(\mathrm{~min}), k_{i d}\left(\mathrm{mg} \cdot \mathrm{g}^{-1} \cdot \mathrm{min}^{-1}\right)$ is the intraparticle diffusion rate constant, and $C$ is the intercept of the plot of $q_{t}$ against $t^{0.5}$, providing information about the thickness of the boundary layer. The greater the value of $C$ is, the greater the effect of the boundary layer on the adsorption is [51].

2.3.8. Thermodynamic Analysis. Thermodynamic parameters including the standard Gibbs energy change $\left(\Delta G^{\circ}\right)$, the enthalpy change $\left(\Delta H^{\circ}\right)$, and the entropy change $\left(\Delta S^{\circ}\right)$ of the adsorption reactions of $\mathrm{Fe}(\mathrm{II})$ and $\mathrm{Cu}(\mathrm{II})$ were determined by using the following equations:

$$
\begin{aligned}
\Delta G^{\circ} & =-R T \ln K_{c}, \\
K_{c} & =\frac{1000 q_{e}}{C_{e}},
\end{aligned}
$$

where $R\left(8.314 \times 10^{-3} \mathrm{~kJ} \cdot \mathrm{mol}^{-1} \cdot \mathrm{K}^{-1}\right)$ represented the molar gas constant, $T$ is the temperature $(K)$, and $K_{c}$ is the distribution coefficient at different temperatures $\left(20,30^{\circ} \mathrm{C}\right.$, and $40^{\circ} \mathrm{C}$ ). The equilibrium constant $K_{c}$ was related to the change of the Gibbs free energy process. To make $K_{c}$ dimensionless, $q_{e}$ was multiplied by 1000 before taking the logarithm [55-57]. In addition, the change in the Gibbs free energy was related to the change sof enthalpy and entropy at a constant temperature, according to the following equation:

$$
\Delta G^{\circ}=\Delta H-T \Delta S^{\circ} \text {. }
$$

Values of $\Delta H^{\circ}$ and $\Delta S^{\circ}$ were calculated from the slope and intercept of the linear plots of $-\Delta G^{\circ}$ versus $T$ (Figure S1). The slope and intercept of the plot gave the $\Delta S^{\circ}$ and the $-\Delta H^{\circ}$ values, respectively.

\section{Results and Discussion}

3.1. Characterization of Polymer Samples. The obtained spectra of CS, CS-genipin, and CS-GG beads determined by FTIR analysis are presented in Figure 1. The CS selected in the present study possessed a DDA of $89 \%$, indicating $89 \%$ of glucosamine and $11 \%$ of acetyl-glucosamine. For this reason, the native CS absorption spectrum showed two specific absorption bands (Figure 1(a)), the first one located at $1650 \mathrm{~cm}^{-1}$ was related to acetyl-glucosamine, and the second one at $1550 \mathrm{~cm}^{-1}$ was attributed to the primary amine (planning vibration) from glucosamine. This confirmed the presence of residual $\mathrm{N}$-acetyl groups in CS, as it was previously reported [58]. When CS was cross-linked with genipin, the absorption bands at 1655 and $1575 \mathrm{~cm}^{-1}$ disappeared (Figure 1(b)), and a new absorption band located at $1640 \mathrm{~cm}^{-1}$ was related to the carbonyl from genipin. In 


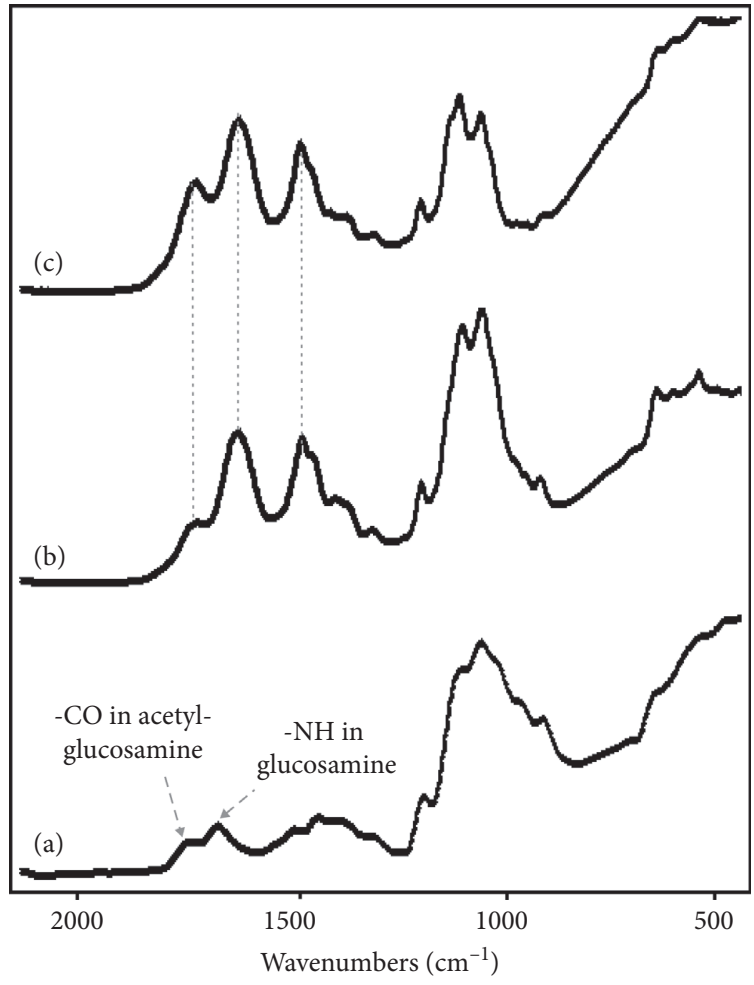

FIGURE 1: FTIR spectra of CS (a), CS-genipin (b), and CS-GG beads (c). For more details, see Materials and Methods.

addition, the comparison of CS-GG and CS-genipin spectrum presented no significant differences (Figure 1(c)). However, the intensity of the absorption band at $1550 \mathrm{~cm}^{-1}$ appeared to be related to the carbonyl from genipin, and the absorption band from the carboxyl of GSH was significantly increased.

The TGA analysis showed that thermogravimetric curves (TG) displayed three important phases for CS beads (Figure 2(a)) and CS-GG beads (Figure 2(b)). The weight loss of CS beads was $12.8 \%$ under the temperature range of $30^{\circ} \mathrm{C}-170^{\circ} \mathrm{C}$, and this was attributed to the moisture in the beads. The TG curve showed a mass loss of $38.31 \%$ under $175^{\circ} \mathrm{C}-650^{\circ} \mathrm{C}, 37.42 \%$ under $675^{\circ} \mathrm{C}$ to $870^{\circ} \mathrm{C}$, and $5.05 \%$ under $875^{\circ} \mathrm{C}$ to $999.1^{\circ} \mathrm{C}$. However, the CS-GG beads were thermally more stable than CS beads, and the loss due to the moisture was $5.35 \%$ in the temperature range of $30^{\circ} \mathrm{C}-178^{\circ} \mathrm{C}$. In addition, the TG curve showed a 36.05 and $20.59 \%$ weight loss under the range of $178^{\circ} \mathrm{C}-276^{\circ} \mathrm{C}$ and $290^{\circ} \mathrm{C}-825^{\circ} \mathrm{C}$, respectively. These results were attributed to the splitting of the saccharide rings. Furthermore, the TG curve indicated a final weight loss for the CS beads of about $93.53 \%$, while for CS-GG beads, it was about $68.99 \%$ at $999.1^{\circ} \mathrm{C}$. These results confirmed the modification of the native CS beads by genipin cross-linking and the functionalization of GSH, giving the property to be more thermally stable. This can be explained by the formation of a rigid polymer network, resulting in a higher thermally stable composite.

The elemental analysis of carbon, azote, and sulfur was performed on the beads, and the weight ratio of $\mathrm{C}, \mathrm{N}$, and $\mathrm{S}$ for CS beads was found to be $40.48,6.76$, and $0 \%$, respectively. In a previous study, similar values in CS were found for $\mathrm{C}, \mathrm{N}$, and $\mathrm{S}$ contents with $40.2,7.41$, and $0 \%$, respectively [59]. Our results did suggest a high purity of the CS used. The proportions of $\mathrm{C}, \mathrm{N}$, and $\mathrm{S}$ contents in CS-GG beads were $68.57,18.31$, and $0.72 \%$, respectively. In fact, the percentage of $\mathrm{S}$ was directly proportional to the amount of GSH functionalized into the beads.

The obtained SEM photography showed the surface morphology of CS beads (Figures 3(a) and 3(b) and CS-GG beads (Figures 3(c) and 3(d). The micrographs presented the homogeneity of the adsorbent, and the presence or not of voids and aggregates onto the surface. In fact, the surface of CS-GG beads was more uniform than the surface of CS beads, indicating a better homogenization film of crosslinked chitosan. In addition, the AFM was used on CS-GG beads to obtain a detailed observation of the nanocomposite film surface at high resolution (Figure 4). The obtained AFM image of CS-GG beads revealed the presence of voids onto the surface.

3.2. Optimization of the Adsorption Capacity for CS-GG Beads. The effects of $\mathrm{pH}$, temperature, contact time, initial concentration of metal ions in solution, and thermodynamic and adsorption kinetic parameters were investigated on the adsorption capacity of $\mathrm{Fe}(\mathrm{II})$ and $\mathrm{Cu}(\mathrm{II})$ on CS-GG beads.

3.2.1. Effect of $p H$. It is well known that the $\mathrm{pH}$ is one of the most important factors during the adsorption process, since it can affect the speciation and the solubility of metal ions, their concentration, the functional groups of the adsorbent, and the degree of ionization during the reaction [60-63]. In 


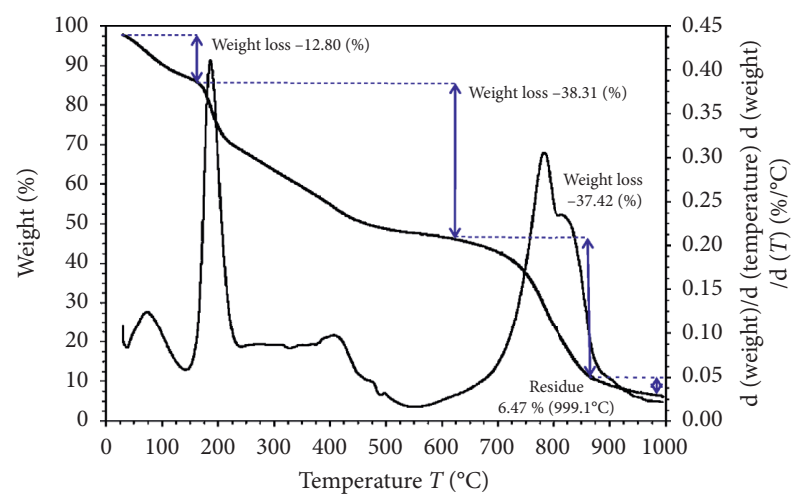

(a)

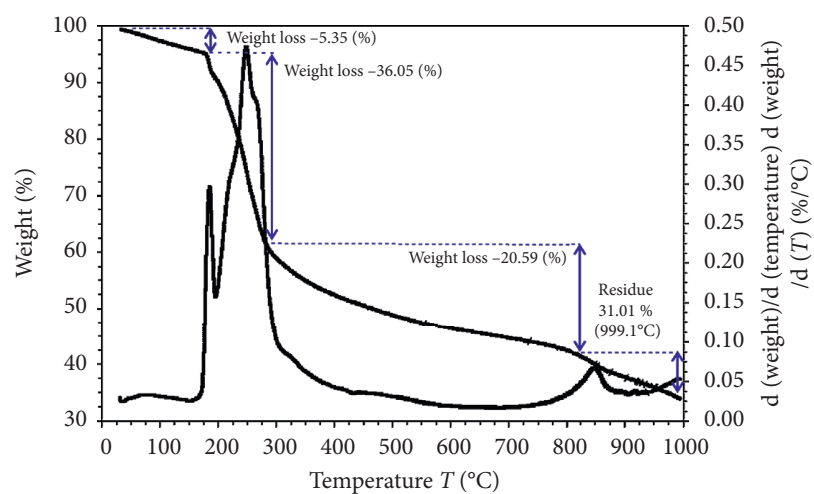

(b)

Figure 2: Thermogravimetric analysis of CS beads (a) and CS-GG beads (b).

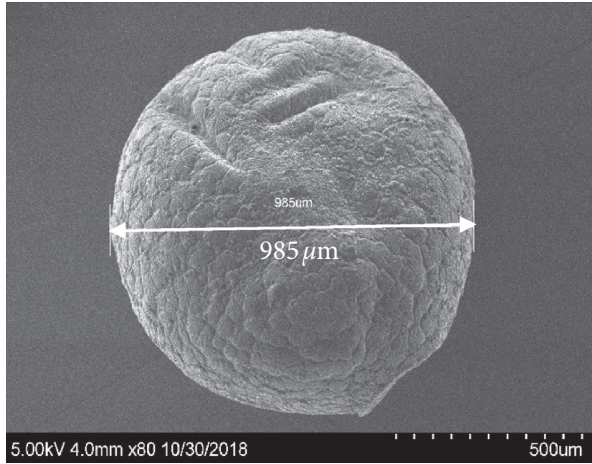

(a)

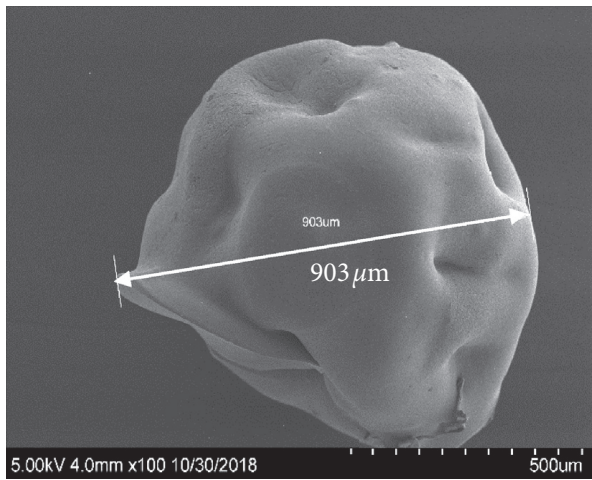

(c)

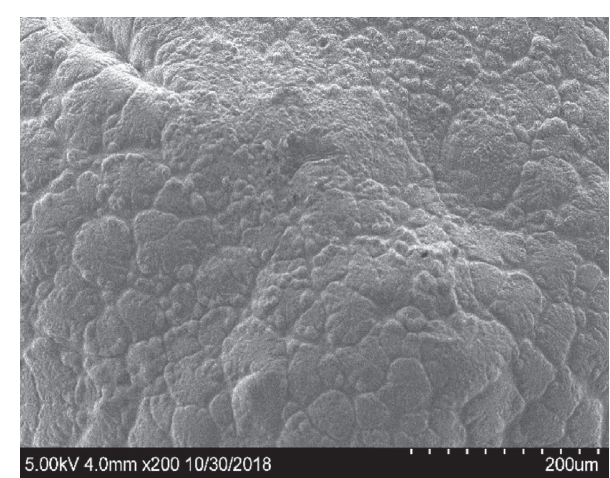

(b)

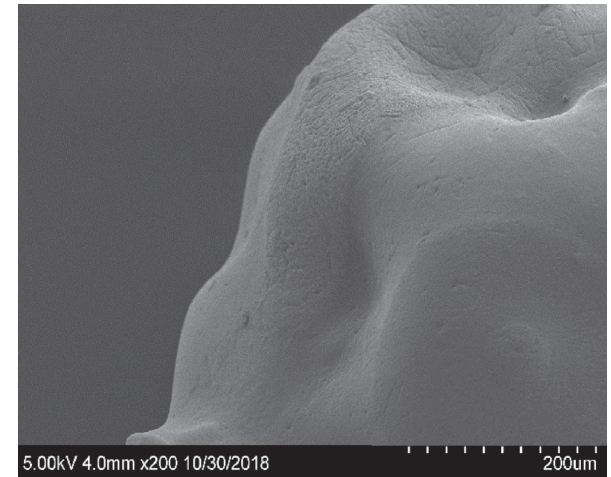

(d)

FIGURE 3: SEM photography showing the surface morphology of CS beads (a, b) and CS-GG beads (c, d).

this study, adsorption experiments were conducted in the $\mathrm{pH}$ range of 2-6 for $\mathrm{Fe}(\mathrm{II})$ and 2-7 for $\mathrm{Cu}(\mathrm{II})$. However, $\mathrm{Fe}(\mathrm{II})$ and $\mathrm{Cu}(\mathrm{II})$ precipitated as insoluble hydroxides at $\mathrm{pH}>6$ and at $\mathrm{pH}>7$, respectively. Figure 5(a) showed that increasing the $\mathrm{pH}$ values of the solution from 2 to 5 induced an increase of the adsorption capacity for $\mathrm{Fe}(\mathrm{II})$ and $\mathrm{Cu}(\mathrm{II})$. According to previous studies, when the $\mathrm{pH}$ of the medium was low, the high concentration of proton $\left(\mathrm{H}^{+}\right)$did occupy most of the adsorption-binding sites at the surface of the adsorbent (i.e., protonation of the amino group). The $\mathrm{H}^{+}$did compete with metal ions, causing a decrease in adsorption efficiency [60-63]. In our study, the CS-GG beads were protonated and gained electrostatic properties $\left(-\mathrm{COO}^{-}\right.$, $\left.-\mathrm{NH}_{3}{ }^{+},-\mathrm{SH}\right)$. However, it is most likely that the binding of divalent metal ions $\mathrm{Fe}(\mathrm{II})$ and $\mathrm{Cu}(\mathrm{II})$ was stronger than $\mathrm{H}^{+}$, since the electrostatic interaction between the pair of electrons on the nitrogen atom and the metal ion was stronger than $\mathrm{H}^{+}$. In addition, there was a mechanism of ion exchange or competitive adsorption between the metal ions and the $\mathrm{H}^{+}$on the amino group $[62,63]$. Moreover, the increase in 


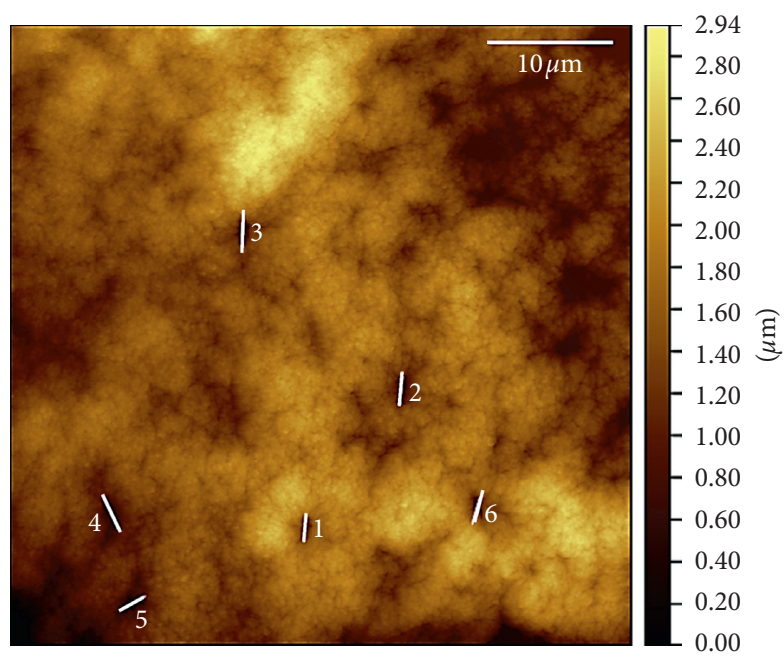

FIgURE 4: AFM image of CS-GG beads.

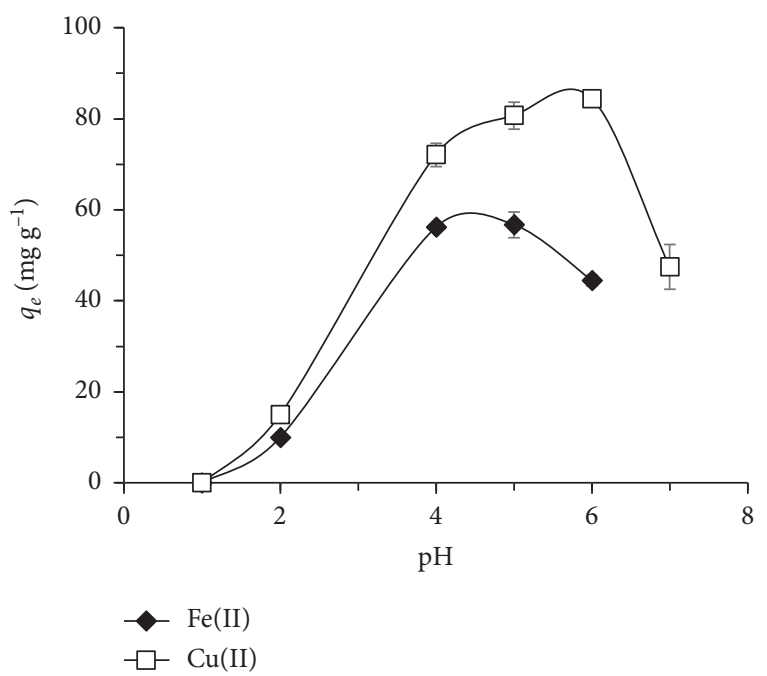

(a)

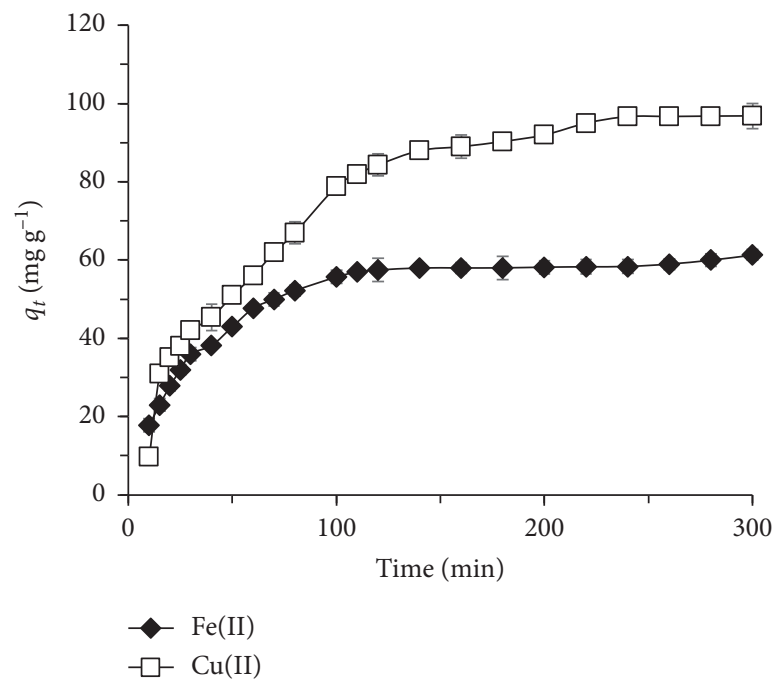

(c)

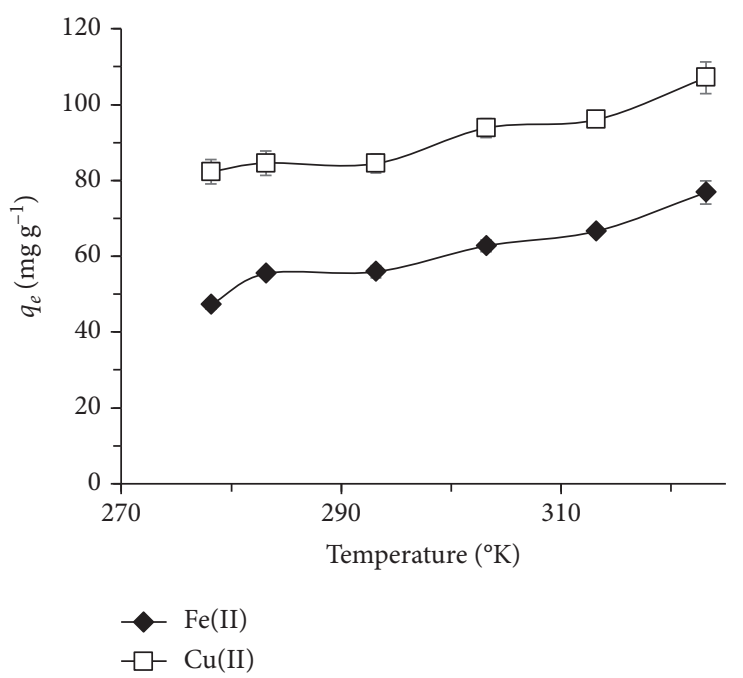

(b)

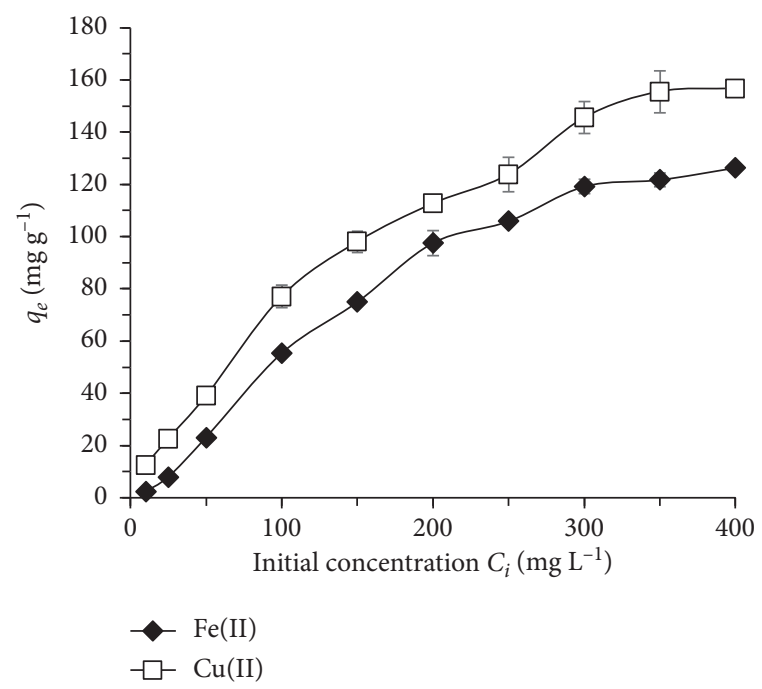

(d)

FiguRE 5: Effect of the initial pH (a), the temperature (b), the contact time (c), and the initial concentration of metal ions in solution (d) on the adsorption capacity of CS-GG beads for $\mathrm{Fe}(\mathrm{II})$ and $\mathrm{Cu}(\mathrm{II})$. The error bars represent the standard deviation of measurements for three sample runs $(n=3)$. 
TABle 1: Thermodynamic parameters for the adsorption of Fe(II) and $\mathrm{Cu}(\mathrm{II})$ ions on CS-GG beads at different temperatures.

\begin{tabular}{lccc}
\hline & & $\mathrm{Fe}(\mathrm{II})$ & $\mathrm{Cu}(\mathrm{II})$ \\
\hline$\Delta \mathrm{H}^{\circ} \mathrm{kJ} \cdot \mathrm{mol}^{-1}$ & & 8.88 & 5.49 \\
$\Delta \mathrm{G}^{\circ} \mathrm{kJ} \cdot \mathrm{mol}^{-1}$ & $-293 \mathrm{~K}$ & -16.39 & -17.24 \\
& $-303 \mathrm{~K}$ & -17.32 & -18.19 \\
& $-313 \mathrm{~K}$ & -18.08 & -18.79 \\
$\Delta \mathrm{S}^{\circ} \mathrm{J} \cdot \mathrm{mol}^{-1} \cdot \mathrm{K}^{-1}$ & & 0.087 & 0.078 \\
$R^{2}$ & & 0.993 & 0.984 \\
\hline
\end{tabular}

Experimental condition: volume of $50 \mathrm{~mL} ; \mathrm{pH}=5$ for $\mathrm{Fe}(\mathrm{II})$ and 6 for $\mathrm{Cu}(\mathrm{II}) ;[\mathrm{Fe}(\mathrm{II}), \mathrm{Cu}(\mathrm{II})]=100 \mathrm{mgL}^{-1}$; adsorbent net mass $=0.030 \mathrm{~g}$; temperature $=293,303$, and $313^{\circ} \mathrm{K}$; contact time $=2 \mathrm{~h}$; shaking rate $=150 \mathrm{rpm}$.

the $\mathrm{pH}$ value induced a decrease in the protonation of the amine groups, facilitating the deprotonation of both carboxylic and - $\mathrm{SH}$ groups, and releasing more binding sites. This reaction might increase the coordination sites for metal ions on CS-GG beads and the formation of an inner-sphere complex by a surface chelation ion exchange $[43,62,63]$. This explanation agreed with our obtained results concerning the increase in the adsorption capacity of metal ions shown in Figure 5(a). Therefore, we found that the optimum $\mathrm{pH}$ for the adsorption of $\mathrm{Fe}(\mathrm{II})$ and $\mathrm{Cu}(\mathrm{II})$ onto CS-GG beads was 5 and 6 , respectively.

3.2.2. Effect of Temperature. The effect of temperature on the adsorption capacity of CS-GG beads for $\mathrm{Fe}(\mathrm{II})$ and $\mathrm{Cu}$ (II) was investigated under the range of $20^{\circ} \mathrm{C}$ to $40^{\circ} \mathrm{C}$ (Figure 5(b)). During these experiments, all the other parameters were kept constant at their optimum values, including a $\mathrm{pH}$ of 5 for $\mathrm{Fe}(\mathrm{II})$ and 6 for $\mathrm{Cu}(\mathrm{II})$, an adsorbent quantity of $0.03 \mathrm{~g}$, and a contact time of $120 \mathrm{~min}$. The results showed that the adsorption capacity increased from 47.26 to $76.87 \mathrm{mg} \cdot \mathrm{g}^{-1}$, in the temperature range tested for $\mathrm{Fe}(\mathrm{II})$. Concerning $\mathrm{Cu}(\mathrm{II})$, the adsorption capacity increased from 82.26 to $107.11 \mathrm{mg} \cdot \mathrm{g}^{-1}$ under the same range of temperature (Figure 5(b)). The enhancement in adsorption capacity was correlated with the increase in temperature. This can be attributed to a higher number of active surface sites available during the adsorption and to an increase in porosity and pore volume of the adsorbent [64]. Therefore, the correlation between the adsorption capacity and the temperature indicated that the adsorption reaction of $\mathrm{Fe}(\mathrm{II})$ and $\mathrm{Cu}(\mathrm{II})$ ions on CS-GG beads was endothermic.

3.2.3. Thermodynamic Analysis. Thermodynamic parameters characterizing the adsorption reaction of $\mathrm{Fe}(\mathrm{II})$ and $\mathrm{Cu}(\mathrm{II})$ onto CS-GG beads were analyzed, such as the changes in Gibbs standard energy $\left(\Delta G^{\circ}\right)$, in enthalpy $\left(\Delta H^{\circ}\right)$, and in entropy $\left(\Delta S^{\circ}\right)$, and the results were presented in Table 1 . Based on thermodynamics, since the reaction did take place in an isolated system, the energy in the system could not be gained or lost, and the entropy change would be the only driving force [65]. Our results showed that the negative value of the Gibbs free energy $\left(\Delta G^{\circ}<0\right)$ increased in relation to the increase in temperature, indicating the probability and spontaneity of both $\mathrm{Fe}$ (II) and $\mathrm{Cu}(\mathrm{II})$ adsorption reactions onto CS-GG beads. The positive value of the enthalpy change $\left(\Delta H^{\circ}>0\right)$ of $\mathrm{Fe}(\mathrm{II})$ and $\mathrm{Cu}(\mathrm{II})$ adsorption reactions indicated the endothermic property of these reactions. In addition, the positive value of the entropy change $\left(\Delta S^{\circ}>0\right)$ indicated that the number of species at the solid-liquid interface increased as well as the randomness at the interface. This was presumably due to the release of aqua molecules when $\mathrm{Fe}$ (II) or $\mathrm{Cu}(\mathrm{II})$ was adsorbed at the surface of the adsorbent.

3.2.4. Effect of $\mathrm{Fe}(\mathrm{II})$ and $\mathrm{Cu}(\mathrm{II})$ Concentration. The adsorption experiments were carried out at different initial concentrations of $\mathrm{Fe}(\mathrm{II})$ and $\mathrm{Cu}(\mathrm{II})$ ranging from 10 to $400 \mathrm{mg} \cdot \mathrm{L}^{-1}$ during $120 \mathrm{~min}$ and under optimal $\mathrm{pH}$ conditions of 5 and 6 for $\mathrm{Fe}(\mathrm{II})$ and $\mathrm{Cu}(\mathrm{II})$, respectively. The effect of the initial concentration of both tested metals on the adsorption capacity of CS-GG beads is presented in Figure 5(d). The results showed that the quantity of adsorbed metal ions increased gradually with the increase of the initial concentration of metal ions in the solution, until reaching a saturation plateau. The adsorption capacity was $126.35 \mathrm{mg} \cdot \mathrm{g}^{-1}$ and $156.69 \mathrm{mg} \cdot \mathrm{g}^{-1}$ for $\mathrm{Fe}(\mathrm{II})$ and $\mathrm{Cu}(\mathrm{II})$, respectively. Concerning $\mathrm{Cu}$ (II), the high adsorption capacity was attributed to its strong affinity for the chitosan. In fact, the increase in the initial concentration of metal ions would induce an increase in the motive force. In CS-GG beads, the sulfur, the nitrogen, and the oxygen atoms with free electrons would have a stronger interaction with metal ions.

3.2.5. Adsorption Isotherm. Here, we applied adsorption isotherms to better understand the mechanism of $\mathrm{Fe}$ (II) and $\mathrm{Cu}$ (II) adsorption reactions onto CS-GG beads, such as the distribution of the adsorbent molecules between the liquid and solid phases once the equilibrium state is reached. Both models of Langmuir and Freundlich isotherms were used to determine the adsorption isotherm data from the experiments. The Langmuir isotherm assumed that the adsorption process occurred homogeneously on a monolayer within the adsorbent until reaching a saturation level. This model considers that all adsorption sites involved are energetically identical (homogeneous) and the intermolecular force will decrease as the distance from the adsorption surface increase [66, 67]. The isotherm of Freundlich was also applied, by considering that the adsorption reaction might occur on a multilayer and an energetically heterogeneous surface. However, the empirical equation of this model is suitable for high- and middle-concentration range. Therefore, this isotherm was not suitable in our study under low-concentration range, since Henry's law was not met. This isotherm permitted only to describe the nonideal and reversible adsorption.

The calculated Langmuir and Freundlich parameters were presented in Table 2 . The maximum adsorption values for Fe(II) were 208.33, 212.77, and $243.90 \mathrm{mg} \cdot \mathrm{g}^{-1}$ under 293, 3033 , and $313^{\circ} \mathrm{K}$, respectively. The values for $\mathrm{Cu}$ (II) were $217.39,263.15$, and $277.77 \mathrm{mg} \cdot \mathrm{g}^{-1}$ under 293, 3033, and $313^{\circ} \mathrm{K}$, respectively. The values of the maximum adsorption capacity $\left(q_{\max }\right)$ obtained from Langmuir isotherm were much higher than the measured $q_{\max }$ for both $\mathrm{Fe}(\mathrm{II})$ and 
TABLe 2: Parameters of Langmuir and Freundlich isotherms for the adsorption reaction of Fe(II) and Cu(II) onto CS-GG beads.

\begin{tabular}{|c|c|c|c|c|c|c|}
\hline Metal ions & \multicolumn{6}{|c|}{ Langmuir } \\
\hline Temp. ${ }^{\circ} \mathrm{K}$ & Measured $q_{\max } \mathrm{mg} \cdot \mathrm{g}^{-1}$ & $K_{L} \mathrm{~L} \cdot \mathrm{mg}^{-1}$ & $q_{\max } \mathrm{mg} \cdot \mathrm{g}^{-1}$ & $R_{L}$ & $R^{2}$ & \\
\hline & 293 & 126.4 & 0.0046 & 208.33 & 0.666 & 0.975 \\
\hline \multirow[t]{3}{*}{$\mathrm{Fe}(\mathrm{II})$} & 303 & 147.5 & 0.0071 & 212.77 & 0.530 & 0.988 \\
\hline & 313 & 152.3 & 0.0055 & 243.90 & 0.578 & 0.981 \\
\hline & 293 & 156.4 & 0.0070 & 217.39 & 0.526 & 0.977 \\
\hline \multirow[t]{5}{*}{$\mathrm{Cu}(\mathrm{II})$} & 303 & 189.5 & 0.0076 & 263.15 & 0.522 & 0.995 \\
\hline & 313 & 199.0 & 0.0072 & 277.77 & 0.520 & 0.974 \\
\hline & \multicolumn{6}{|c|}{ Freundlich } \\
\hline & Temp. ${ }^{\circ} \mathrm{K}$ & $\operatorname{Ln} K_{F}$ & \multicolumn{2}{|c|}{$n$} & \multicolumn{2}{|c|}{$R^{2}$} \\
\hline & 293 & & & & \\
\hline \multirow[t]{3}{*}{$\mathrm{Fe}(\mathrm{II})$} & 303 & 0.212 & \multicolumn{2}{|c|}{1.16} & \multicolumn{2}{|c|}{0.960} \\
\hline & 313 & 0.332 & \multicolumn{2}{|c|}{1.03} & \multicolumn{2}{|c|}{0.969} \\
\hline & 293 & 1.178 & \multicolumn{2}{|c|}{1.47} & \multicolumn{2}{|c|}{0.974} \\
\hline \multirow[t]{2}{*}{$\mathrm{Cu}(\mathrm{II})$} & 303 & 1.235 & \multicolumn{2}{|c|}{1.40} & \multicolumn{2}{|c|}{0.981} \\
\hline & 313 & 1.418 & \multicolumn{2}{|c|}{1.43} & \multicolumn{2}{|c|}{0.979} \\
\hline
\end{tabular}

Experimental condition: volume $50 \mathrm{~mL}$; pH5 for $\mathrm{Fe}(\mathrm{II})$ and 6 for $\mathrm{Cu}(\mathrm{II}),[\mathrm{Fe}(\mathrm{II}), \mathrm{Cu}(\mathrm{II})]=10-400 \mathrm{mgL}^{-1}$; adsorbent net mass $=0.030 \mathrm{~g}$; temperature $=293$, 303 , and $313^{\circ} \mathrm{K}$; contact time $=2 \mathrm{~h}$, shaking rate $=150 \mathrm{rpm}$.

$\mathrm{Cu}(\mathrm{II})$. However, the adsorption capacity for $\mathrm{Cu}(\mathrm{II})$ was still higher than the one for $\mathrm{Fe}(\mathrm{II})$. In addition, $K_{L}$ in Langmuir isotherm was higher for $\mathrm{Cu}(\mathrm{II})$ compared to $K_{L}$ for $\mathrm{Fe}(\mathrm{II})$. Our results are consistent with previous studies, in which the CS showed a good affinity and selectivity for $\mathrm{Cu}(\mathrm{II})[68,69]$. In addition, $\mathrm{Cu}$ complexes with ammonia were stable, indicating that the CS was selective for this metal ion. This indicated that our beads showed better adsorption rates for $\mathrm{Cu}$ (II) compared to $\mathrm{Fe}$ (II). In addition, the higher affinity for $\mathrm{Cu}(\mathrm{II})$ can be explained by the Jahn-Teller effect, which is known to be predominant for $\mathrm{Cu}$ complexes $[65,70]$. All of $R_{L}$ values found were between 0 and $1\left(0<R_{L}<1\right)$ under the studied concentration and temperature range (Figure S2 and Table 2), indicating the adsorption affinity of Fe(II) and $\mathrm{Cu}$ (II) onto CS-GG beads. Based on the Freundlich isotherm, the $K_{F}$ value obtained for $\mathrm{Cu}(\mathrm{II})$ was higher than the value for $\mathrm{Fe}(\mathrm{II})$. A previous study showed that the tested adsorbent had a more homogeneous distribution of binding sites if the parameter $n$ (or $1 / n$ ) value was close to 1 or even to 1 [23]. Our results showed that the values of $1 / n$ obtained for both $\mathrm{Fe}(\mathrm{II})$ and $\mathrm{Cu}(\mathrm{II})$ were 0.91 and 0.70 , respectively, suggesting that the binding sites were more homogeneous for the adsorption of $\mathrm{Fe}(\mathrm{II})$ and $\mathrm{Cu}(\mathrm{II})$ at the solid-liquid interface. Moreover, our data was better correlated with the Langmuir isotherm $\left(R^{2}>0.98\right)$ than the Freundlich isotherm. Therefore, our results suggested that the adsorption reactions of $\mathrm{Fe}(\mathrm{II})$ and $\mathrm{Cu}(\mathrm{II})$ did occur as a monolayer mechanism onto the CS-GG beads.

3.2.6. Effect of Contact Time. Since the time to reach an adsorption equilibrium represents an important parameter, we analyzed the effect of contact time on the adsorption capacity of CS-GG beads for $\mathrm{Fe}(\mathrm{II})$ and $\mathrm{Cu}$ (II). The removal of $\mathrm{Fe}(\mathrm{II})$ and $\mathrm{Cu}(\mathrm{II})$ from the solution in relation to the contact time is presented in Figure 5(c). The results showed that the maximum adsorption was following the order $\mathrm{Cu}(\mathrm{II})>\mathrm{Fe}$ (II) at all time intervals. It also showed that an increase in the agitation time improved the removal of these metal ions until reaching equilibrium after $120 \mathrm{~min}$ and 180 min, respectively, for $\mathrm{Fe}(\mathrm{II})$ and $\mathrm{Cu}(\mathrm{II})$. The adsorption equilibrium between the two metals was different, since $\mathrm{Cu}(\mathrm{II}) \mathrm{had}$ a greater affinity for thiol hydroxyl and amino groups [71, 72].

3.2.7. Adsorption Kinetic Analysis. The kinetic rates were analyzed to provide information on the adsorption mechanism such as the rate-limiting step including the diffusion control, the chemical reaction, and the particle diffusion. To evaluate the kinetic mechanism controlling the adsorption process, the experimental data were analyzed by using the pseudo-first-order, the pseudo-secondorder, and the intraparticle diffusion kinetic models. The parameters $k_{1}, k_{2}$, and $k_{i d}$ and $R^{2}$ values of the kinetic models were presented in Table 3. The data plot of the pseudo-first-order model was linear with $R^{2}<0.99$, suggesting that the adsorption of both $\mathrm{Fe}(\mathrm{II})$ and $\mathrm{Cu}(\mathrm{II})$ did not follow this model. The value of the linear regression coefficient $R^{2}$ was higher than 0.99 and closer to 1 $\left(0.99<R^{2}<1\right)$, which suggested that the adsorption of ions followed the pseudo-second-order model describing chemisorption. Such adsorption mechanism involved the valence forces by sharing or exchanging electrons between the metals and the adsorbent without any mass transfer in solution $[23,73]$.

The results in Figure 6 presented the plots of $\mathrm{Fe}(\mathrm{II})$ and $\mathrm{Cu}$ (II) adsorbed per unit mass of CS-GG versus $\mathrm{t}^{0.5}\left(\min ^{0.5}\right)$. The change of $q_{\mathrm{t}}$ indicated that the adsorption reaction for both metal ions had two steps. Each linear portion of the curve of $q_{\mathrm{t}}$ as a function of $\mathrm{t}^{0.5}$ corresponded to a step. It suggested that the first step described the adsorption process at the surface of CS-GG beads. In the second step, progressive adsorption did occur during which the intraparticle diffusion had control over the speed of the reaction [74]. However, the intraparticular diffusion would become the limiting step only if the curve did pass through the origin. In fact, the two curves (Figure 6) did not go through the origin, 
TABLE 3: Kinetic parameters of the pseudo-first-order, the pseudo-second-order, and the internal diffusion models.

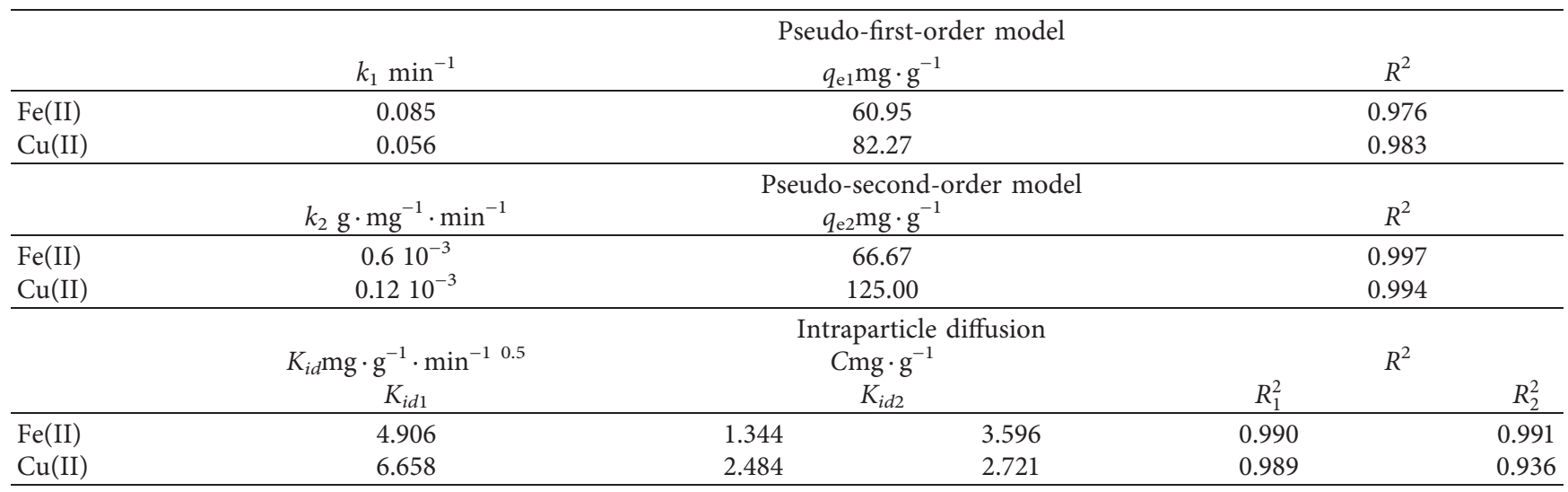

Experimental condition: volume $50 \mathrm{~mL} ; \mathrm{pH}=5$ for $\mathrm{Fe}(\mathrm{II})$ and 6 for $\mathrm{Cu}(\mathrm{II}) ;[\mathrm{Fe}(\mathrm{II}), \mathrm{Cu}(\mathrm{II})]=100 \mathrm{mgL}^{-1}$; adsorbent net mass $=0.030 \mathrm{~g}$; temperature $=293^{\circ} \mathrm{K}$; contact time $=10 \mathrm{~min}$, during $5 \mathrm{~h}$; shaking rate $=150 \mathrm{rpm}$.

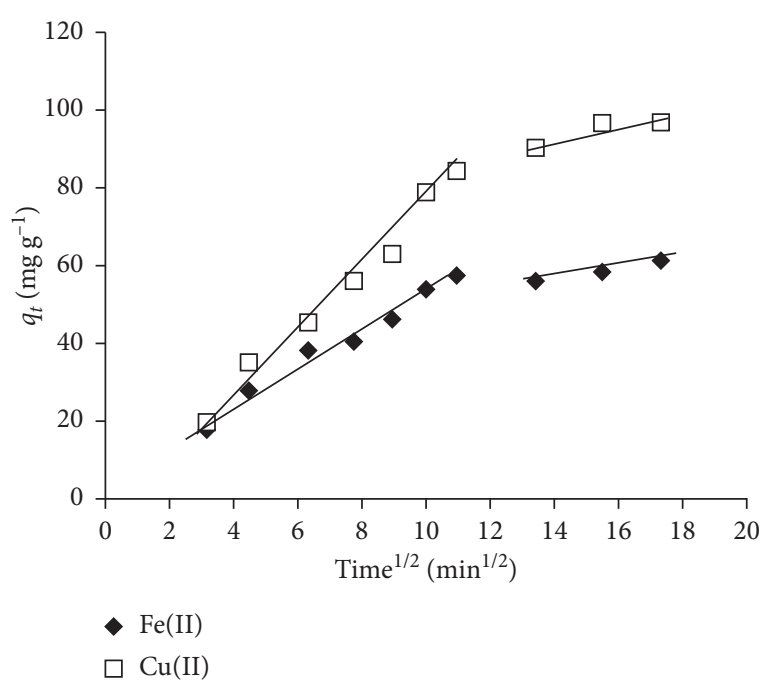

FIGURE 6: Internal diffusion indicated by the plot of $\mathrm{q}_{\mathrm{t}}$ of $\mathrm{Fe}(\mathrm{II})$ and $\mathrm{Cu}(\mathrm{II})$ in relation to the time.

which might be due to the difference in the rate of mass transfer at the initial and final stages of the adsorption reaction. Moreover, it indicated that the internal diffusion was not the only step controlling the reaction speed in our study. A similar result was reported by Debnath et al. [57]. Therefore, the adsorption reaction of both $\mathrm{Fe}(\mathrm{II})$ and $\mathrm{Cu}(\mathrm{II})$ at the surface of CS-GG beads was correlated with the initial metal concentration.

3.2.8. Comparative Studies. The adsorption capacity of CSGG beads was dependent on its chemical structure and the number of functional groups at the surface of the polymer. Thus, we compared the maximal adsorption capacity of different CS-modified beads with our new CS-GG beads (Table 4). The maximum adsorption capacity of $\mathrm{Fe}(\mathrm{II})$ on
TABLE 4: Maximum adsorption capacity of different modified chitosan adsorbents for $\mathrm{Fe}(\mathrm{II})$ and $\mathrm{Cu}(\mathrm{II})$ in aqueous solution.

\begin{tabular}{lc}
\hline Adsorbent & $q_{\max }\left(\mathrm{mg} \cdot \mathrm{g}^{-1}\right)$ \\
& $\mathrm{Fe}(\mathrm{II})$ \\
\hline $\begin{array}{l}\text { Chitosan cross-linked with glutaraldehyde [75] } \\
\text { Chitosan cross-linked with epichlorohydrin [75] }\end{array}$ & 47.25 \\
$\begin{array}{l}\text { Chitosan cross-linked with ethylene glycol } \\
\text { diglycidyl ether [75] }\end{array}$ & 38.47 \\
$\begin{array}{l}\text { Mayflower seed carbon [76] } \\
\text { Functionalized-glutathione on chitosan-genipin } \\
\text { cross-linked beads (CS-GG) }\end{array}$ & 49.75 \\
\hline & 126.4 \\
$\begin{array}{l}\text { Chitosan nanofibrils [23] } \\
\text { Tannin-phenolic immobilized on cellulose [77] }\end{array}$ & $\mathrm{Cu}(\mathrm{II})$ \\
$\begin{array}{l}\text { Chitosan/polyvinylalcohol/polyethyleneimine } \\
\text { membrane [78] }\end{array}$ & 55.97 \\
$\begin{array}{l}\text { Magnetic-epichlorohydrin cross-linked chitosan } \\
\text { [14] }\end{array}$ & 86.08 \\
$\begin{array}{l}\text { Chitosan cross-linked with epichlorohydrin- } \\
\text { triphosphate [79] }\end{array}$ & 123.10 \\
$\begin{array}{l}\text { Functionalized-glutathione on chitosan-genipin } \\
\text { cross-linked beads (CS-GG) }\end{array}$ & 130.72 \\
\hline
\end{tabular}

CS-GG beads was the highest when compared to the other CS beads. In fact, this adsorption capacity was related to the concentration of GSH added to the formulation. As shown in Figure 7, a significant difference was noticed between the adsorption of metals on CS beads without GSH and CS-GG beads, which was correlated with the amount of functionalized GSH on CS-GG beads. In fact, it is well known that GSH can make complexes with metals due to the amino acid cysteine present in the $\gamma$-Glu-Cys-Gly structure $[44,45]$. Concerning the removal of $\mathrm{Cu}(\mathrm{II})$, only the $\mathrm{CS}$ nanofibrils had a higher adsorption capacity than our CS-GG beads. Therefore, a comparison between our study and previous reports clearly indicated that the CS-GG beads were an effective adsorbent for the removal of $\mathrm{Cu}$ (II) and $\mathrm{Fe}$ (II) from aqueous solution. 


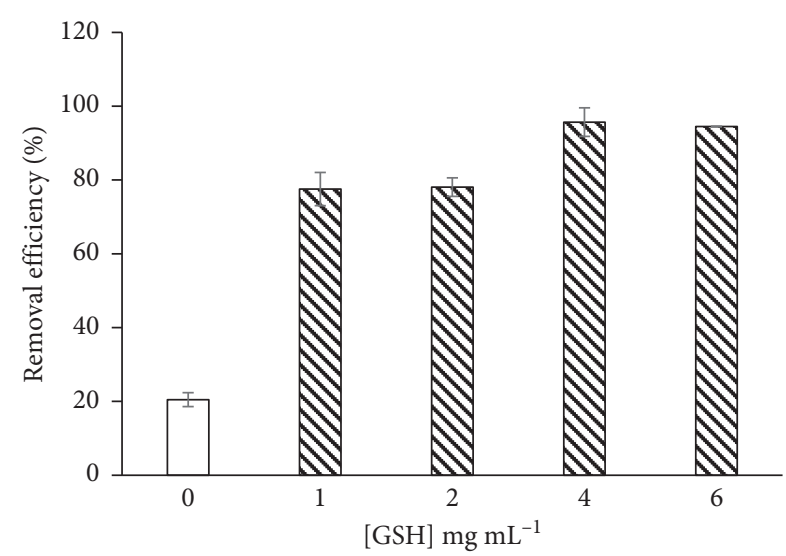

FIGURE 7: The adsorption of Fe(II) on CS-genipin (blank) and CSGG beads (dashes) functionalized with different concentrations of GSH. The error bars represent the standard deviation of measurements for three sample runs $(n=3)$.

\section{Conclusions}

In this study, we used the natural cross-linker genipin to successfully cross-link CS beads before to be functionalized with GSH. The newly formed CS-GG beads were characterized and tested as an adsorbent for the removal of $\mathrm{Fe}$ (II) and $\mathrm{Cu}(\mathrm{II})$ from aqueous solutions. We demonstrated that different parameters affected the adsorption reaction on the beads such as the $\mathrm{pH}$, the contact time, the temperature, and the initial concentration of metals. According to the obtained results, the optimum $\mathrm{pH}$ for the adsorption of $\mathrm{Fe}(\mathrm{II})$ and $\mathrm{Cu}(\mathrm{II})$ was 5 and 6 , respectively. In addition, the pseudosecond-order equation gave the best correlation coefficient, indicating that the chemical adsorption process was the ratelimiting step without a mass transfer in solution. The adsorption reaction of $\mathrm{Fe}(\mathrm{II})$ and $\mathrm{Cu}(\mathrm{II})$ was dependent on the temperature degree. Moreover, our results suggested that the Langmuir isotherm was the best fitting model with the acquired adsorption data for both tested metals than the Freundlich isotherm. According to the Langmuir isotherm, the maximum adsorption capacities of $\mathrm{Fe}$ (II) and $\mathrm{Cu}$ (II) evaluated on CS-GG beads were 208.33 and $217 \mathrm{mg} \cdot \mathrm{g}^{-1}$, respectively. Based on the thermodynamic analysis, we showed that the adsorption process was spontaneous and endothermic. Therefore, this study demonstrated that the new synthesized CS-GG beads can be used as an efficient adsorbent for trace metals in aqueous solution. In this perspective, this new material should be further tested for the joint removal of a mixture of trace metals in solution to be applied for water decontamination.

\section{Data Availability}

The datasets analyzed in this manuscript are available on request to the corresponding author.

\section{Conflicts of Interest}

The authors declare that there are no conflicts of interest regarding the publication of this paper.

\section{Acknowledgments}

This study was financially supported by the Individual Discovery Grant awarded to Prof. David Dewez from the Natural Sciences and Engineering Research Council of Canada (NSERC, RGPIN 415572-2013).

\section{Supplementary Materials}

Figure S1: thermodynamic plots of $-\Delta \mathrm{G}^{\circ}$ in relation to temperature $\left({ }^{\circ} \mathrm{K}\right)$. Figure S2: Langmuir plots of experimental data of $C_{\mathrm{e}} / q_{\mathrm{e}}$ versus $C_{\mathrm{e}}$ for $\mathrm{Fe}(\mathrm{II})$ and $\mathrm{Cu}(\mathrm{II})$ adsorption on CS-GG beads. Figure S3: Freundlich plots of experimental data showing $\operatorname{Ln} q_{\mathrm{e}}$ versus $\operatorname{Ln} C_{\mathrm{e}}$ for the adsorption of $\mathrm{Fe}(\mathrm{II})$ and $\mathrm{Cu}(\mathrm{II})$ on CS-GG beads. Figure S4: pseudo-first-order of the adsorption of $\mathrm{Fe}(\mathrm{II})$ (a) and $\mathrm{Cu}(\mathrm{II})$ (b) on CS-GG beads. Figure S5: pseudo-second-order of the adsorption of Fe(II) (a) and $\mathrm{Cu}(\mathrm{II})$ (b) on CS-GG beads. (Supplementary Materials)

\section{References}

[1] J. P. Vareda, A. J. M. Valente, and L. Durães, "Assessment of heavy metal pollution from anthropogenic activities and remediation strategies: a review," Journal of Environmental Management, vol. 246, pp. 101-118, 2019.

[2] K. H. Vardhan, P. S. Kumar, and R. C. Panda, "A review on heavy metal pollution, toxicity and remedial measures: current trends and future perspectives," Journal of Molecular Liquids, vol. 290, p. 111197, 2019.

[3] M. A. Hassaan, A. El Nemr, and F. F. Madkour, "Environmental assessment of heavy metal pollution and human health risk," American Journal of Water Science and Engineering, vol. 2, no. 3, pp. 14-19, 2016.

[4] C. Andreini, I. Bertini, G. Cavallaro, G. L. Holliday, and J. M. Thornton, "Metal ions in biological catalysis: from enzyme databases to general principles," JBIC Journal of Biological Inorganic Chemistry, vol. 13, no. 8, pp. 1205-1218, 2008.

[5] C. Ferousi, S. Lindhoud, F. Baymann, B. Kartal, M. S. Jetten, and J. Reimann, "Iron assimilation and utilization in anaerobic ammonium oxidizing bacteria," Current Opinion in Chemical Biology, vol. 37, pp. 129-136, 2017.

[6] N. Raffa, N. Osherov, and N. P. Keller, "Copper utilization, regulation, and acquisition by Aspergillus fumigatus," International Journal of Molecular Sciences, vol. 20, no. 8, p. 1980, 2019.

[7] World Health Organization, "Acceptability aspects: taste, odour and appearance," Guidelines for Driking-Water Quality (GDWQ), pp. 219-350, WHO Library Cataloguing-in-Publication Data, Geneva, Switzerland, 4th edition, 2011.

[8] G. Michalakos, J. M. Nieva, D. Vayenas, and G. Lyberatos, "Removal of iron from potable water using a trickling filter," Water Research, vol. 31, no. 5, pp. 991-996, 1997.

[9] J. Hartmann, F. Braulke, U. Sinzig et al., "Iron overload impairs proliferation of erythroid progenitors cells (BFU-E) from patients with myelodysplastic syndromes," Leukemia Research, vol. 37, no. 3, pp. 327-332, 2013.

[10] M. Araya, B. Chen, L. M. Klevay et al., "Confirmation of an acute no-observed-adverse-effect and low-observed-adverseeffect level for copper in bottled drinking water in a multi-site international study," Regulatory Toxicology and Pharmacology, vol. 38, no. 3, pp. 389-399, 2003. 
[11] A. Dorsey and L. Ingerman, Toxicological Profile for Copper, ATSDR, Atlanta, GA, USA, 2004.

[12] Z. Mehrani, H. Ebrahimzadeh, A. A. Asgharinezhad, and E. Moradi, "Determination of copper in food and water sources using poly $\mathrm{m}$-phenylenediamine/CNT electrospun nanofiber," Microchemical Journal, vol. 149, p. 103975, 2019.

[13] F. Fu and Q. Wang, "Removal of heavy metal ions from wastewaters: a review," Journal of Environmental Management, vol. 92, no. 3, pp. 407-418, 2011.

[14] Y. Gutha, Y. Zhang, W. Zhang, and X. Jiao, "Magnetic-epichlorohydrin crosslinked chitosan schiff's base (m-ECCSB) as a novel adsorbent for the removal of $\mathrm{Cu}$ (II) ions from aqueous environment," International Journal of Biological Macromolecules, vol. 97, pp. 85-98, 2017.

[15] G. K. Sarma, S. Sen Gupta, and K. G. Bhattacharyya, "Nanomaterials as versatile adsorbents for heavy metal ions in water: a review," Environmental Science and Pollution Research, vol. 26, no. 7, pp. 6245-6278, 2019.

[16] N. G. Kandile and A. S. Nasr, "New hydrogels based on modified chitosan as metal biosorbent agents," International Journal of Biological Macromolecules, vol. 64, pp. 328-333, 2014.

[17] A. K. Rathoure, J. Anuradha, R. Sanjeevi, D. S. Chauhan, and S. Tripathi, "Effective removal of heavy metals from aqueous solution by nano-composites: bioremediation using nano technology," in Biostimulation Remediation Technologies for Groundwater Contaminants, pp. 249-258, IGI Global, Hershey, PA, USA, 2018.

[18] B. Wang, Z. Bai, H. Jiang et al., "Selective heavy metal removal and water purification by microfluidically-generated chitosan microspheres: characteristics, modeling and application," Journal of Hazardous Materials, vol. 364, pp. 192-205, 2019.

[19] V. Alimohammadi, M. Sedighi, and E. Jabbari, "Experimental study on efficient removal of total iron from wastewater using magnetic-modified multi-walled carbon nanotubes," Ecological Engineering, vol. 102, pp. 90-97, 2017.

[20] R. El Haouti, Z. Anfar, A. Chennah et al., "Synthesis of sustainable mesoporous treated fish waste as adsorbent for copper removal," Groundwater for Sustainable Development, vol. 8, pp. 1-9, 2019.

[21] Y. Sun, K. J. Shah, W. Sun, and H. Zheng, "Performance evaluation of chitosan-based flocculants with good $\mathrm{pH}$ resistance and high heavy metals removal capacity," Separation and Purification Technology, vol. 215, pp. 208-216, 2019.

[22] G. Z. Kyzas, G. Bomis, R. I. Kosheleva et al., "Nanobubbles effect on heavy metal ions adsorption by activated carbon," Chemical Engineering Journal, vol. 356, pp. 91-97, 2019.

[23] D. Liu, Z. Li, Y. Zhu, Z. Li, and R. Kumar, "Recycled chitosan nanofibril as an effective $\mathrm{Cu}(\mathrm{II}), \mathrm{Pb}(\mathrm{II})$ and $\mathrm{Cd}(\mathrm{II})$ ionic chelating agent: adsorption and desorption performance," Carbohydrate Polymers, vol. 111, pp. 469-476, 2014.

[24] H. L. Vasconcelos, V. T. Fávere, N. S. Gonçalves, and M. C. M. Laranjeira, "Chitosan modified with Reactive Blue 2 dye on adsorption equilibrium of $\mathrm{Cu}$ (II) and $\mathrm{Ni}$ (II) ions," Reactive and Functional Polymers, vol. 67, no. 10, pp. 10521060, 2007.

[25] S. Gu, X. Kang, L. Wang, E. Lichtfouse, and C. Wang, "Clay mineral adsorbents for heavy metal removal from wastewater: a review," Environmental Chemistry Letters, vol. 17, no. 2, pp. 629-654, 2019.

[26] Z. Anfar, A. Amedlous, A. Ait El Fakir et al., "Combined methane energy recovery and toxic dye removal by porous carbon derived from anaerobically modified digestate," ACS Omega, vol. 4, no. 5, pp. 9434-9445, 2019.
[27] Z. Anfar, M. Zbair, H. A. Ahsaine et al., "Preparation and characterization of porous carbon@ZnO-NPs for organic compounds removal: classical adsorption versus ultrasound assisted adsorption," ChemistrySelect, vol. 4, no. 17, pp. 4981-4994, 2019.

[28] H. Haffad, M. Zbair, Z. Anfar, H. Ait Ahsaine, H. Bouhlal, and K. Hamza, "Removal of reactive red-198 dye using chitosan as an adsorbent: optimization by central composite design coupled with response surface methodology," Toxin Reviews, vol. 1-13, 2019.

[29] K. Manzoor, M. Ahmad, S. Ahmad, and S. Ikram, "Removal of $\mathrm{Pb}$ (ii) and $\mathrm{Cd}$ (ii) from wastewater using arginine cross-linked chitosan-carboxymethyl cellulose beads as green adsorbent," RSC Advances, vol. 9, no. 14, pp. 7890-7902, 2019.

[30] L. Zhang, Y. Zeng, and Z. Cheng, "Removal of heavy metal ions using chitosan and modified chitosan: a review," Journal of Molecular Liquids, vol. 214, pp. 175-191, 2016.

[31] A. S. Pedro, E. Cabral-Albuquerque, D. Ferreira, and B. Sarmento, "Chitosan: an option for development of essential oil delivery systems for oral cavity care?" Carbohydrate Polymers, vol. 76, no. 4, pp. 501-508, 2009.

[32] S. Pap, C. Kirk, B. Bremner et al., "Synthesis optimisation and characterisation of chitosan-calcite adsorbent from fisheryfood waste for phosphorus removal," Environmental Science and Pollution Research, vol. 27, no. 9, 2020.

[33] E. Igberase, A. Ofomaja, and P. O. Osifo, "Enhanced heavy metal ions adsorption by 4 -aminobenzoic acid grafted on chitosan/epichlorohydrin composite: kinetics, isotherms, thermodynamics and desorption studies," International Journal of Biological Macromolecules, vol. 123, pp. 664-676, 2019.

[34] G. Martínez-Mejía, N. A. Vázquez-Torres, A. CastellRodríguez, J. M. del Río, M. Corea, and R. Jiménez-Juárez, "Synthesis of new chitosan-glutaraldehyde scaffolds for tissue engineering using Schiff reactions," Colloids and Surfaces A: Physicochemical and Engineering Aspects, vol. 579, p. 123658, 2019.

[35] E. Guibal, "Interactions of metal ions with chitosan-based sorbents: a review," Separation and Purification Technology, vol. 38, no. 1, pp. 43-74, 2004.

[36] N. Li and R. Bai, "Copper adsorption on chitosan-cellulose hydrogel beads: behaviors and mechanisms," Separation and Purification Technology, vol. 42, no. 3, pp. 237-247, 2005.

[37] Q. Jiang, N. Reddy, S. Zhang, N. Roscioli, and Y. Yang, "Waterstable electrospun collagen fibers from a non-toxic solvent and crosslinking system," Journal of Biomedical Materials Research Part A, vol. 101A, no. 5, pp. 1237-1247, 2013.

[38] L. Rachmawati and M. Udkhiyati, “Toxicity test of chromium and glutaraldehyde to determine greener chemical in tannery industry," Materials Science Forum, vol. 901, pp. 160-165, 2017.

[39] Y. Sun, C. Zhu, W. Sun et al., "Plasma-initiated polymerization of chitosan-based CS-g-P(AM-DMDAAC) flocculant for the enhanced flocculation of low-algal-turbidity water," Carbohydrate Polymers, vol. 164, pp. 222-232, 2017.

[40] R. A. A. Muzzarelli, F. Tanfani, S. Mariotti, and M. Emanuelli, "Preparation and characteristic properties of dithiocarbamate chitosan, a chelating polymer," Carbohydrate Research, vol. 104, no. 2, pp. 235-243, 1982.

[41] E. Guibal, N. Von Offenberg Sweeney, T. Vincent, and J. M. Tobin, "Sulfur derivatives of chitosan for palladium sorption," Reactive and Functional Polymers, vol. 50, no. 2, pp. 149-163, 2002.

[42] G. Cárdenas, P. Orlando, and T. Edelio, "Synthesis and applications of chitosan mercaptanes as heavy metal retention 
agent," International Journal of Biological Macromolecules, vol. 28, no. 2, pp. 167-174, 2001.

[43] Y. G. Abou El-Reash, "Magnetic chitosan modified with cysteine-glutaraldehyde as adsorbent for removal of heavy metals from water," Journal of Environmental Chemical Engineering, vol. 4, no. 4, pp. 3835-3847, 2016.

[44] H. C. Park, J. E. Hwang, Y. Jiang et al., "Functional characterisation of two phytochelatin synthases in rice ( Oryza sativa cv. Milyang 117) that respond to cadmium stress," Plant Biology, vol. 21, no. 5, pp. 854-861, 2019.

[45] M. A. Younes, L. A. Nicaise, and M. B. Bertrand, "Polymerization degree of phytochelatin in contaminated soil phytoremediation of manganese in Hibiscus sabdariffa linn var sabdariffa," European Scientific Journal, ESJ, vol. 12, no. 33, pp. 482-492, 2016.

[46] F.-L. Mi, H.-W. Sung, S.-S. Shyu, C.-C. Su, and C.-K. Peng, "Synthesis and characterization of biodegradable TPP/genipin co-crosslinked chitosan gel beads," Polymer, vol. 44, no. 21, pp. 6521-6530, 2003.

[47] A. Khan, S. Salmieri, C. Fraschini, J. Bouchard, B. Riedl, and M. Lacroix, "Genipin cross-linked nanocomposite films for the immobilization of antimicrobial agent," ACS Applied Materials \& Interfaces, vol. 6, no. 17, pp. 15232-15242, 2014.

[48] J. Roether, C. Oelschlaeger, and N. Willenbacher, "Hyaluronic acid cryogels with non-cytotoxic crosslinker genipin," $\mathrm{Ma}$ terials Letters: X, vol. 4, p. 100027, 2019.

[49] Z. Aksu, "Determination of the equilibrium, kinetic and thermodynamic parameters of the batch biosorption of nickel(II) ions onto Chlorella vulgaris," Process Biochemistry, vol. 38, no. 1, pp. 89-99, 2002.

[50] E. Osagie and C. N. Owabor, "Adsorption of benzene in batch system in natural clay and sandy soil," Advances in Chemical Engineering and Science, vol. 5, no. 3, pp. 352-361, 2015.

[51] L. Largitte and R. Pasquier, "A review of the kinetics adsorption models and their application to the adsorption of lead by an activated carbon," Chemical Engineering Research and Design, vol. 109, pp. 495-504, 2016.

[52] S. K. Lagergren, "About the theory of so-called adsorption of soluble substances," Sven Vetenskapsakad Handingarl, vol. 24, pp. 1-39, 1898.

[53] Y. S. Ho and G. McKay, "Pseudo-second order model for sorption processes," Process Biochemistry, vol. 34, no. 5, pp. $451-465,1999$.

[54] W. J. Weber and J. C. Morris, "Kinetics of adsorption on carbon from solution," Journal of the Sanitary Engineering Division, vol. 89, pp. 31-60, 1963.

[55] S. Canzano, P. Iovino, S. Salvestrini, and S. Capasso, "Comment on "Removal of anionic dye Congo red from aqueous solution by raw pine and acid-treated pine cone powder as adsorbent: equilibrium, thermodynamic, kinetics, mechanism and process design," Water Research, vol. 46, no. 13, pp. 4314-4315, 2012.

[56] S. Dawood and T. K. Sen, "Removal of anionic dye Congo red from aqueous solution by raw pine and acid-treated pine cone powder as adsorbent: equilibrium, thermodynamic, kinetics, mechanism and process design," Water Research, vol. 46, no. 6, pp. 1933-1946, 2012.

[57] S. Debnath, A. Maity, and K. Pillay, "Magnetic chitosan-GO nanocomposite: synthesis, characterization and batch adsorber design for $\mathrm{Cr}(\mathrm{VI})$ removal," Journal of Environmental Chemical Engineering, vol. 2, no. 2, pp. 963-973, 2014.

[58] M. Fernandes Queiroz, K. Melo, D. Sabry, G. Sassaki, and H. Rocha, "Does the use of chitosan contribute to oxalate kidney stone formation?" Marine Drugs, vol. 13, no. 1, pp. 141-158, 2014.

[59] Z. M. Dos Santos, A. L. P. F. Caroni, M. R. Pereira, D. R. da Silva, and J. L. C. Fonseca, "Determination of deacetylation degree of chitosan: a comparison between conductometric titration and CHN elemental analysis," Carbohydrate Research, vol. 344, no. 18, pp. 2591-2595, 2009.

[60] M. N. Saifuddin and P. Kumaran, "Removal of heavy metal from industrial wastewater using chitosan coated oil palm shell charcoal," Electronic Journal of Biotechnology, vol. 8, pp. 43-53, 2005.

[61] G. A. Mahmoud, "Adsorption of copper(II), lead(II), and cadmium(II) ions from aqueous solution by using hydrogel with magnetic properties," Monatshefte für Chemie-Chemical Monthly, vol. 144, no. 8, pp. 1097-1106, 2013.

[62] Z. Cheng, X. Liu, M. Han, and W. Ma, "Adsorption kinetic character of copper ions onto a modified chitosan transparent thin membrane from aqueous solution," Journal of Hazardous Materials, vol. 182, no. 1-3, pp. 408-415, 2010.

[63] Y.-M. Hao, C. Man, and Z.-B. Hu, "Effective removal of $\mathrm{Cu}$ (II) ions from aqueous solution by amino-functionalized magnetic nanoparticles," Journal of Hazardous Materials, vol. 184, no. 1-3, pp. 392-399, 2010.

[64] X. Jiao, Y. Gutha, and W. Zhang, "Application of chitosan/ poly(vinyl alcohol)/CuO (CS/PVA/CuO) beads as an adsorbent material for the removal of $\mathrm{Pb}$ (II) from aqueous environment," Colloids and Surfaces B: Biointerfaces, vol. 149, pp. 184-195, 2017.

[65] M. Monier, D. M. Ayad, and D. A. Abdel-Latif, "Adsorption of $\mathrm{Cu}(\mathrm{II}), \mathrm{Cd}(\mathrm{II})$ and $\mathrm{Ni}(\mathrm{II})$ ions by cross-linked magnetic chitosan-2-aminopyridine glyoxal Schiff's base," Colloids and Surfaces B: Biointerfaces, vol. 94, pp. 250-258, 2012.

[66] N. Ünlü and M. Ersoz, "Adsorption characteristics of heavy metal ions onto a low cost biopolymeric sorbent from aqueous solutions," Journal of Hazardous Materials, vol. 136, no. 2, pp. 272-280, 2006.

[67] M. Uysal and I. Ar, "Removal of $\mathrm{Cr}(\mathrm{VI})$ from industrial wastewaters by adsorption," Journal of Hazardous Materials, vol. 149, no. 2, pp. 482-491, 2007.

[68] I. M. N. Vold, K. M. Vårum, E. Guibal, and O. Smidsrød, "Binding of ions to chitosan-selectivity studies," Carbohydrate Polymers, vol. 54, no. 4, pp. 471-477, 2003.

[69] A. J. Varma, S. V. Deshpande, and J. F. Kennedy, "Metal complexation by chitosan and its derivatives: a review," Carbohydrate Polymers, vol. 55, no. 1, pp. 77-93, 2004.

[70] L. Zhou, Y. Wang, Z. Liu, and Q. Huang, "Characteristics of equilibrium, kinetics studies for adsorption of $\mathrm{Hg}(\mathrm{II}), \mathrm{Cu}(\mathrm{II})$, and $\mathrm{Ni}$ (II) ions by thiourea-modified magnetic chitosan microspheres," Journal of Hazardous Materials, vol. 161, no. 2-3, pp. 995-1002, 2009.

[71] V. W. D. Chui, K. W. Mok, C. Y. Ng, B. P. Luong, and K. K. Ma, "Removal and recovery of copper(II), chromiu$\mathrm{m}$ (III), and nickel(II) from solutions using crude shrimp chitin packed in small columns," Environment International, vol. 22, no. 4, pp. 463-468, 1996.

[72] B. Hultberg, A. Andersson, and A. Isaksson, "Copper ions differ from other thiol reactive metal ions in their effects on the concentration and redox status of thiols in HeLa cell cultures," Toxicology, vol. 117, no. 2-3, pp. 89-97, 1997.

[73] M. Hasan, A. L. Ahmad, and B. H. Hameed, "Adsorption of reactive dye onto cross-linked chitosan/oil palm ash composite beads," Chemical Engineering Journal, vol. 136, no. 2-3, pp. 164-172, 2008. 
[74] S. J. Allen, G. McKay, and K. Y. H. Khader, "Intraparticle diffusion of a basic dye during adsorption onto sphagnum peat," Environmental Pollution, vol. 56, no. 1, pp. 39-50, 1989.

[75] W. S. W. Ngah, S. Ab Ghani, and A. Kamari, "Adsorption behaviour of $\mathrm{Fe}$ (II) and $\mathrm{Fe}$ (III) ions in aqueous solution on chitosan and cross-linked chitosan beads," Bioresource Technology, vol. 96, no. 4, pp. 443-450, 2005.

[76] P. Shanmughaprabha, S. Sasireka, S. Sabarathinam, and G. Selvakumari, "Efficiency of may flower seed carbon to uptake $\mathrm{Fe}(\mathrm{II})$ from aqueous solution: kinetic and isotherm studies," Environmental Progress \& Sustainable Energy, vol. 38, pp. S243-S249, 2018.

[77] P. Zhou, H. Yuan, L. Ou, and P. Zhiyuan, "Removal of Cd(II) and $\mathrm{Cu}(\mathrm{II})$ ions from aqueous solutions using tannin-phenolic polymer immobilized on cellulose," Journal of Macromolecular Science, Part A, vol. 56, no. 7, pp. 717-722, 2019.

[78] N. Sahebjamee, M. Soltanieh, S. M. Mousavi, and A. Heydarinasab, "Removal of $\mathrm{Cu} 2+, \mathrm{Cd} 2+$ and $\mathrm{Ni} 2+$ ions from aqueous solution using a novel chitosan/polyvinyl alcohol adsorptive membrane," Carbohydrate Polymers, vol. 210, pp. 264-273, 2019.

[79] R. Laus, T. G. Costa, B. Szpoganicz, and V. T. Fávere, "Adsorption and desorption of $\mathrm{Cu}(\mathrm{II}), \mathrm{Cd}(\mathrm{II})$ and $\mathrm{Pb}(\mathrm{II})$ ions using chitosan crosslinked with epichlorohydrin-triphosphate as the adsorbent," Journal of Hazardous Materials, vol. 183, no. 1-3, pp. 233-241, 2010. 